\title{
Evaluation of antioxidant activity of alcohol-free Moru wine using on-line HPLC
}

\author{
Ha Gyoon Na, Yun Ju Cha, Ji Woo Shin, Jun Hyung Kim, Hyeon Uk Son, \\ Yong Woon Shin, Min Young Jung, Moon Suk Choi, Ki-Hyo Jang* \\ Department of Food and Nutrition, Kangwon National University, Samcheok 25949, Korea
}

\section{On-line HPLC법에 의한 무알코올 머루 발효액의 항산화능 평가}

\author{
나하균 · 차윤주 · 신지우 · 김준형 · 손현욱 · 신용운 · 정민영 · 최문석 · 장기효* \\ 강원대학교 식품영양학과
}

\begin{abstract}
In this study, the chemical composition and antioxidant activities of Moru wine and alcohol-free Moru wine were evaluated. To prepare the alcohol-free analogue, Moru wine was subjected to either atmospheric distillation (NA-AD) or vacuum distillation $\left(80 \mathrm{mbar}, 55^{\circ} \mathrm{C}, \mathrm{NA}-\mathrm{VD}\right)$. Among the three different preparations of Moru wines, namely, Moru wine, NA-AD, and NA-VD, the total acidity was the highest in NA-VD, while the soluble solid content was the highest in Moru wine. The total phenolic content, total flavonoid content, and ABTS radical scavenging activity were the highest in NA-AD. The three different preparations of Moru wines were examined by an on-line high-performance liquid chromatography (HPLC)-2,2'-azino-bis(3-ethylbenzothiazoline-6-sulphonic acid) (ABTS)-based assay to identify the compounds responsible for the radical scavenging activity of wines. The results obtained for NA-AD and NA-VD in the on-line screening HPLC-ABTS assay were similar. At least 10 different compounds, namely, gallic acid, protocatechuic acid, chlorogenic acid, vanillic acid, caffeic acid, syringic acid, t-ferulic acid, rutin, naringin, and t-cinnamic acid, were identified from Moru wine, NA-AD, and NA-VD. Gallic acid (10.35-24.69 $\mu \mathrm{g} / \mathrm{mL})$ and syringic acid $(9.29-43.98 \mu \mathrm{g} / \mathrm{mL})$ were found to be the major polyphenols in Moru wine, NA-AD, and NA-VD.
\end{abstract}

Key words : alcohol-free, antioxidant activity, HPLC, Moru wine, phenolic compounds

\section{서 론}

경제성장과 국민소득의 증가로 인하여 항산화, 항암 및 면역, 각종 질병 예방 등의 기능성을 강조한 식품에 대한 국민들의 소비가 증가되고 있다(1). 그 중에서도, 포도주 소비와 심혈관계질환 발병 비율의 상관성이 알려진 이후 과실주에 대한 관심이 증대해 왔다 $(2,3)$. 머루(Vitis amurensis)는 포도나무과 덩굴성 목본식물로 직경 $8 \mathrm{~mm}$

*Corresponding author. E-mail : kihyojang@kangwon.ac.kr Phone : 82-33-540-3312, Fax : 82-33-540-3319

Received 17 October 2018; Revised 9 December 2018; Accepted 11 December 2018.

Copyright (c) The Korean Society of Food Preservation. All rights reserved.
정도의 작은 검붉은색 열매를 생산한다(4). 품종, 숙성기간 및 재배환경에 따른 차이가 있지만, 머루에는 칼슘, 인 및 철 등의 무기질과, 비타민 $\mathrm{B}_{1}, \mathrm{~B}_{2}, \mathrm{~B}_{3}$ 및 비타민 $\mathrm{C}$ 가 풍부하 며, 다양한 항산화 물질들이 포함되어 있다(3,5). 국내에서 생산되는 머루는 과실대비 씨앗의 크기가 큰 이유로 생식용 보다는 대부분 머루와인(Moru wine) 제조용으로 소비된다 $(3,5)$. 최근에는 식품의 이화학적 특성과 기능성은 유지하 면서 위해성을 제거한 제품에 대한 소비자들의 요구가 증가 하고 있다(6). Moru wine에서 건강의 위해요소로 작용하는 알코올은 증류에 의하여 Moru wine에서 선별적으로 제거 할 수 있다.

국내 증류주 제조는 감압증류방식 또는 상압증류방식으 로 제조된다(7,8). Cho 등(9)은 마가목 열매, 사과 및 감귤 등의 과실원료별, 증류방식별로 초류, 본류 및 후류로 구분 
지어 증류한 후, 증류주의 증류효율과 주요 향기성분 비교 시에 상압증류와 감압증류의 유의적인 차이를 보고하였다. 하지만 Moru wine을 활용한 무알코올 음료제조 및 해당 제품의 성분 분석에 관한 연구는 전무한 실정이다. 이에 본 연구에서는 Moru wine을 상압증류법과 감압증류법으로 알코올을 증류시켜 무알코올 와인을 제조한 후, Moru wine 과 2종 무알코올 Moru wine의 성분과 항산화물질의 정성 및 정량 분석을 시도하였다.

\section{재료 및 방법}

\section{실험재료 및 시약}

Acetic acid, sodium hydroxide 및 sodium nitrate은 Showa Chemical Industry Co.(Tokyo, Japan)사 제품을, sodium carbonate은 Samchun Chemical(Pyeongtaek, Korea)사 제품 을, Folin-Ciocalteu's reagent, aluminum nitrate, 2,2'-azinobis(3-ethylbenzothiazoline-6-sulphonic acid)(ABTS), potassium persulfate 및 항산화활성 실험용 표준물질인 gallic acid, protocatechuic acid, chlorogenic acid, vanillic acid, syringic acid, p-coumaric acid, t-ferulic acid, naringin, $t$-cinnamic acid, naringenin, kaempferol, caffeic acid, epicatechin 및 (+)catechin은 Sigma-Aldrich(St. Louis, MO, USA)사 제품 을, rutin은 Wako Pure Chemical Industries(Osaka, Japan)사 제품을 사용하였다. HPLC분석에 사용한 water, methanol, acetonitrile은 Fisher Scientific(Fairlawn, NJ, USA)사 제품을 사용하였다.

\section{Moru wine의 발효 및 증류}

Moru wine은 Lee 등(3)의 방법으로 실험실에서 자체양조 하였다. 파쇄한 머루 $15 \mathrm{~L}$ 를 $25 \mathrm{~L}$ 용량의 플라스틱 발효조에 투입하고, 설탕으로 보당하여 $24^{\circ} \mathrm{Brix}$ 로 조절하였다. 여기 에 살균을 목적으로 $\mathrm{K}_{2} \mathrm{~S}_{2} \mathrm{O}_{5} 2 \mathrm{~g}$ 을 첨가하여 상온에서 16 시 간 동안 정치하였다. 정치 후 Novozyme사(Bagsvaerd, Denmark)의 pectinase인 Pectinex 100 L(5,000 FDU/mL, 5 $\left.5^{\circ} \mathrm{C}\right)$ 을 $5 \mathrm{~mL}$ 가한 후 여기에 다시 Saccharomyces cerevisiae(Red Star Premier cuvee, LeSaffre, Marcqen-Baroeul, France) $5 \mathrm{~g}$ 을 첨가하여 $23^{\circ} \mathrm{C}$ 에서 2 주 동안 발효 하였다. 발효주를 거름망을 통과시켜 고체성분을 제거한 후 Moru wine으로 사용하였다. 무알코올 Moru wine의 제조 를 위하여 상압증류법과 감압증류법을 적용하였다. 상압증 류법을 사용한 시료제조를 위하여 Moru wine $500 \mathrm{~mL}$ 을 $100^{\circ} \mathrm{C}$ 으로 설정된 히팅맨틀(Model ES4, Misung Scientific Co., Seoul, Korea)로 가열하여 연속적으로 증류하였고, 감 압 증류법을 사용한 시료제조를 위하여 $M o r u$ wine $500 \mathrm{~mL}$ 을 압력 $80 \mathrm{mbar}$, 온도 $55^{\circ} \mathrm{C}$ 로 설정된 회전증발농축기 (R-100, BÜCHI, Zollikofen, Switzerland)로 Moru wine을 연
속적으로 증류하여 알코올을 제거하였다. 증류과정 중 Moru wine 시료의 알코올 함량을 Alcolyzer wine(Anton paar, Graz, Austria)으로 측정하였으며, 시료의 알코올 함량 이 $1 \%$ 이하가 되었을 때 증류를 종료하였다. 2 종 무알코올 Moru wine 시료들의 최종 부피는 $360 \mathrm{~mL}$ 였다. 분석에는 증류 전 시료인 머루와인(Moru wine), 상압증류법으로 알 코올을 비롯한 휘발성 성분을 제거한 무알코올 $M o r u$ wine(non-alcoholic Moru wine produced by atmospheric distillation, NA-AD) 및 감압증류법으로 제조한 무알코올 Moru wine(non-alcoholic Moru wine produced by vacuum distillation, NA-VD) 등 총 3종 와인시료들을 사용하였다.

\section{이화학적 품질특성 분석}

시료의 $\mathrm{pH}$ 측정에는 $\mathrm{pH}$ meter(model 725p, Istek, Seoul, Korea)를 사용하였다. 산도측정을 위하여, 시료액 $10 \mathrm{~mL}$ 를 비이커에 담고 페놀프탈레인 지시약 1-2방울을 떨어뜨린 후, $0.1 \mathrm{~N} \mathrm{NaOH}$ 를 천천히 첨가하여 혼합물의 핑크색이 30초 동안 유지되는 점을 종말점으로 하고, 종말점까지 소 모된 $\mathrm{NaOH}$ 양을 측정하여 주석산(tartaric acid) 함량으로 계산하였다. 가용성 고형분 함량은 와인을 굴절당도계 (Model N-1a, ATAGO, Tokyo, Japan)를 이용하여 측정하였 다. 시료의 알코올 함량은 Alcolyzer wine(Anton paar)을 사용하여 측정하였다.

\section{항산화 활성 측정}

총 플라보노이드 함량 측정은 Zhishen 등(10)의 방법을 변형하여 다음과 같이 실시하였다. 시료 $300 \mu \mathrm{L}$ 에 증류수 $300 \mu \mathrm{L}$ 를 첨가한 후 여기에 다시 $5 \%$ sodium nitrite $30 \mu \mathrm{L}$ 를 가하여 5 분 동안 반응시킨 후 추가로 $10 \%$ aluminium nitrate $60 \mu \mathrm{L}$ 를 첨가하여 6분 동안 방치하였다. 반응액에 $1 \mathrm{~N}$ $\mathrm{NaOH} 200 \mu \mathrm{L}$ 를 가하여 microplate reader(Eon, BioTek, Winnoski, VT, USA)로 $510 \mathrm{~nm}$ 파장에서 흡광도를 측정하 였다. 총 플라보노이드 함량은 (+)카테킨(catechin)을 표준 물질로 사용하여 검량선의 회귀식에서 카테킨 당량 $((+)$ catechin equivalent, CE)으로 환산하여 나타내었다. 페 놀성 화합물(total phenolic contents) 함량은 Folin-Ciocalteu's reaction 발색법(11)을 이용하여 다음과 같이 측정하였다. 시료 $200 \mu \mathrm{L}$ 에 Folin-Ciocalteu's reagent $200 \mu \mathrm{L}$ 를 가하여 5 분 동안 반응시킨 후 추가로 $20 \%$ sodium carbonate 400 $\mu \mathrm{L}$ 를 가하여 실온에서 90 분 동안 반응시켜 microplate reader로 $765 \mathrm{~nm}$ 파장에서 흡광도를 측정하였다. 총 폴리페 놀 함량은 갈산(gallic acid)을 표준물질로 사용하여 gallic acid equivalent $(\mathrm{GAE} \mathrm{mg} / \mathrm{L})$ 로 환산하여 나타내었다. ABTS 라디칼 소거능 활성(12)은 다음과 같이 측정하였다. ABTS 라디칼 생성을 위해 $7.4 \mathrm{mM} \mathrm{ABTS}$ 와 $2.6 \mathrm{mM}$ potassium persulfate을 혼합한 용액을 암실에서 24시간 방치하여 라디 칼을 생성하였다. 생성된 $\mathrm{ABTS}$ 라디칼을 $734 \mathrm{~nm}$ 에서 흡광 
도를 측정하여 0.7 이 되도록 희석하여 사용하였다. 희석한 $\mathrm{ABTS}$ 용액 $950 \mu \mathrm{L}$ 에 시료 $50 \mu \mathrm{L}$ 를 넣어 30 분 동안 반응시 킨 후 $734 \mathrm{~nm}$ 에서 흡광도를 측정하였다.

\section{온라인 HPLC 항산화 분석(on-line HPLC-ABTS assay)}

시료 전처리를 위하여 Sep-Pak $\mathrm{C}_{18}$ Vac cartridge(Waters, Milford, MA, USA)에 methanol $5 \mathrm{~mL}$ 를 흘려주어 활성화시 킨 다음, 초순수 water $5 \mathrm{~mL}$ 로 세척하였다. 이어 시료 2 $\mathrm{mL}$ 을 주입한 후 $1 \%$ acetic acid(in 50\% methanol) $10 \mathrm{~mL}$ 로 용출하여 색소, 당류 및 유리당 등을 제거하였다. 용출된 시료 $10 \mathrm{~mL}$ 를 농축하여 $50 \%$ 메탄올 $2 \mathrm{~mL}$ 로 용해하여 0.2 $\mu \mathrm{m}$ PTFE syringe filter로 여과하고 HPLC 분석에 사용하였 다(13). 폴리페놀 분석용 표준물질들은 메탄올에 녹여 $\mathrm{HPLC}$ 분석에 사용하였다. $\mathrm{ABTS}$ 라디칼은 $\mathrm{ABTS}$ 과 potassium persulfate이 각각 $2 \mathrm{mM}$ 와 $3.5 \mathrm{mM}$ 이 되도록 녹여 갈색병에 담아 물로 30 배 희석한 후 24 시간 반응시켜 ABTS 라디칼이 생성되도록 하였으며 이를 ABTS 시약으로 사용 하였다. 온라인 HPLC 항산화 분석법(14)으로 ABTS 라디 칼 제거능을 가진 페놀성 물질들을 아래의 분석조건하에서 정성 및 정량분석하였다. Quaternary pump, variable wavelength detector(VWD), diode array detector(DAD) 및 Agilent Zorbax Eclipse plus $\mathrm{C}_{18}$ 컬럼(4.6×250 mm ID, Agilent Technology, Santa Clara, CA, USA)이 장착된 HPLC(Agilent 1200 series, Agilent Technology)로 온라인 $\mathrm{HPLC}$ 항산화 분석을 실시하였다. 시료의 주입량은 $20 \mu \mathrm{L}$ 였으며, 이동상은 용매 $\mathrm{A}(0.1 \%$ acetic acid in water $)$ 와 용매 $\mathrm{B}(0.1 \%$ acetic acid in acetonitrile)를 95:0(0 min), 70:30(30 $\mathrm{min}), 65: 35(50 \mathrm{~min}), 95: 5(60 \mathrm{~min})$ 의 조건에서 $0.4 \mathrm{~mL} / \mathrm{min}$ 의 유속으로 공급하였다. 첫 번째 검출기의 파장은 $280 \mathrm{~nm}$ 였 다. 첫 번째 검출기를 통과한 혼합용매는 T자 관에서 0.2 $\mathrm{mL} / \mathrm{min}$ 유속으로 공급되는 ABTS 시약과 합류하여 radical 소거반응이 진행되었으며 이후 두 번째 검출기에서 $\mathrm{ABTS}$ radical 소거능을 $734 \mathrm{~nm}$ 에서 측정하였다.

\section{통계처리}

실험 결과는 3회 반복하여 얻은 자료의 평균표푼편차 로 표시하였고, SPSS 23.0(SPSS Inc., Chicago, IL, USA) 통계 프로그램을 사용하여 시료군별 차이를 $\mathrm{p}<0.05$ 수준에 서 one-way ANOVA를 실시하고 Duncan's multiple range test로 시료간의 유의적 차이를 검정하였다.

\section{결과 및 고찰}

\section{이화학적 품질특성}

머루와인(Moru wine), 상압증류 무알코올 Moru wine(NA-AD) 및 감압증류 무알코올 Moru wine(NA-VD)
시료들의 $\mathrm{pH}$, 산도 및 가용성고형분 함량분석 결과는 Table 1 과 같다. 3 종 시료들의 $\mathrm{pH}$ 는 $\mathrm{Moru}$ wine, NA-AD 및 $\mathrm{NA}-\mathrm{VD}$ 시료들에서 각각 $3.96 \pm 0.02, \quad 3.94 \pm 0.01$ 및 $3.94 \pm 0.01$ 로 유의적인 차이가 없었다. 산도의 경우 Moru wine, NA-AD 및 NA-VD 시료들에서 각각 $0.76 \pm 0.01$, $0.89 \pm 0.03$ 및 $1.02 \pm 0.10 \%$ 로 나타났다 $(\mathrm{p}<0.05)$. 이러한 결과 는 Lee 등(3)이 보고한 Moru wine의 산도(1.1\%)와 비슷한 값을 나타내고 있다. 또한 $\mathrm{Ji}$ 등(15)이 보고한 Moru wine의 산도 범위인 0.94-1.18\%와도 유사하였다. Sung 등(16)은 산도는 와인의 품질에 영향을 미치는 중요한 요인으로 산도 가 낮으면 와인은 특색 없는 맛을 내고, 반대로 높으면 강한 신맛을 내므로, 포도와인의 적정산도는 0.56-0.96\%로 제안 하였다. 본 연구에서 증류법(감압증류 및 상압증류)으로 제조한 무알코올 Moru wine 시료들의 산도는 일반적인 포 도와인의 적정산도 범위와 비슷하거나 약간 높게 나타났 다. 일반적으로 $\mathrm{pH}$ 와 산도는 유사한 경향성이 나타나는데 반하여 본 연구에서는 다르게 나타난 것은 증류에 따른 성분의 변화로 추측되나 추가적인 분석은 시도하지 않았 다. 가용성 고형분 함량은 Moru wine, NA-AD 및 NA-VD 시료들에서 각각 $8.40 \pm 0.17,6.00 \pm 0.00$ 및 $6.00 \pm 0.00{ }^{\circ} \mathrm{Brix}$ 로 나타나서 Moru wine에서 가장 높았다(p<0.05). 굴절당도 계에 의한 가용성 고형분 함량 측정에는 당 성분 이외에도 단백질, 에탄올 함량 등이 복합적으로 영향을 주어 ${ }^{\circ}$ Brix 값에 반영된다(3). Table 2에서는 2종 무알코올 Moru wine 시료들이 증류에 따른 시료의 농축효과로 가용성 고형분 함량이 증가가 예상됨에도 불구하고 실제 측정에서는 증류 한 시료들에서 가용성 고형분 함량이 감소되었다. 이러한 상반된 이유로는 증류로 제거된 성분들 중 상당부분이 에탄 올이며, 제거된 에탄올 성분으로 인하여 증류한 시료들에 서 가용성 고형분 함량이 낮게 측정된 것으로 추측된다.

Table 1. Physicochemical properties of Moru wine and nonalcoholic Moru wine

\begin{tabular}{cccc}
\hline Analysis & Moru wine & NA-AD ${ }^{1)}$ & NA-VD \\
\hline $\mathrm{pH}$ & $3.96 \pm 0.02^{3)}$ & $3.94 \pm 0.01$ & $3.94 \pm 0.01$ \\
Titratable acidity (\%) & $0.76 \pm 0.01^{(4)}$ & $0.89 \pm 0.03^{\mathrm{b}}$ & $1.02 \pm 0.11^{\mathrm{a}}$ \\
Soluble solids ('Brix) & $8.40 \pm 0.17^{\mathrm{a}}$ & $6.00 \pm 0.00^{\mathrm{b}}$ & $6.00 \pm 0.00^{\mathrm{b}}$ \\
\hline
\end{tabular}

${ }^{1)}$ Non-alcoholic Moru wine produced by atmospheric pressure method.

${ }^{2)}$ Non-alcoholic Moru wine produced by reduced pressure method.

${ }^{3)}$ All values are mean $\pm \mathrm{SD}(\mathrm{n}=3)$.

${ }^{4)-c}$ Means with different superscripts in the same row are significantly different at $\mathrm{p}<0.05$ by Duncan's multiple range test.

\section{항산화 활성}

3종 시료들의 총 플라보노이드 함량, 총 페놀화합물 함량 및 ABTS 라디칼 소거능을 분석한 결과는 Table 2에 나타내 었다. Moru wine, NA-AD 및 NA-VD의 총 플라보노이드 함량은 각각 $956.29 \pm 20.34,1,832.13 \pm 104.66$ 및 $1,028.44 \pm$ 
Table 2. Antioxidant properties of Moru wine and non-alcoholic Moru wine

\begin{tabular}{cccc}
\hline Analysis & Moru wine & NA-AD & NA-VD $^{12}$ \\
\hline Flavonoid contents (CE $\mu \mathrm{g} / \mathrm{mL})$ & $956.29 \pm 20.34^{3)(4)}$ & $1,832.13 \pm 104.66^{\mathrm{a}}$ & $1,028.44 \pm 39.10^{\mathrm{b}}$ \\
Phenolic contents (GAE $\mu \mathrm{g} / \mathrm{mL})$ & $1,955.00 \pm 75.35^{\mathrm{b}}$ & $3,345.14 \pm 65.72^{\mathrm{a}}$ & $2,194.44 \pm 96.21^{\mathrm{b}}$ \\
ABTS radical scavenging activity $(\%)$ & $92.61 \pm 0.16^{\mathrm{b}}$ & $98.11 \pm 0.16^{\mathrm{a}}$ & $98.16 \pm 0.24^{\mathrm{a}}$ \\
\hline
\end{tabular}

${ }^{1)}$ Non-alcoholic Moru wine produced by atmospheric pressure method.

${ }^{2)}$ Non-alcoholic Moru wine produced by reduced pressure method.

${ }^{3)}$ All values are mean \pm SD $(n=3)$.

${ }^{4)-c}$ Means with different superscripts in the same row are significantly different at $\mathrm{p}<0.05$ by Duncan's multiple range test.

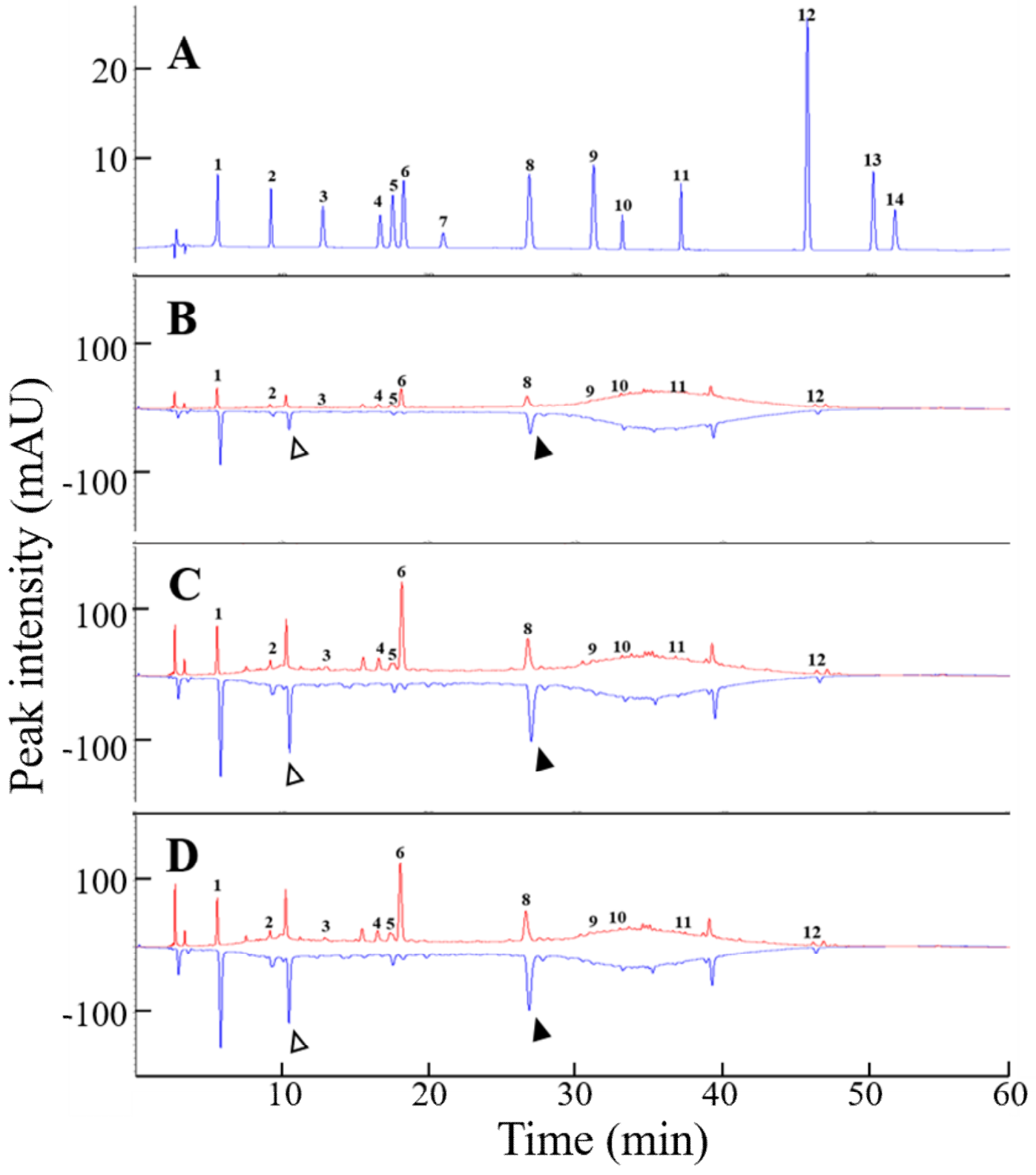

Fig. 1. Chromatogram of 14 standard phenolic compounds (A), Moru wine (B), NA-AD (C), and NA-VD (D).

1, gallic acid; 2, protocatechuic acid; 3, chlorogenic acid; 4, vanillic acid; 5, caffeic acid; 6, syringic acid; 7, epicatechin; 8, p-coumaric acid; 9, t-ferulic acid; 10, rutin; 11, naringin; 12 , t-cinnamic acid; 13 , naringenin; 14 , kaempferol.

$\triangle$ and $\boldsymbol{\Delta}$ symbols represent unknown 1 and unknown 2, respectively. The HPLC chromatogram of the extract was detected at $280 \mathrm{~nm}$ for phenolic compounds and the ABTS radical scavenging activity of each compound was expressed as negative peaks at $734 \mathrm{~nm}$. 
$39.10 \mu \mathrm{g} / \mathrm{mL}$ 로 측정되어 NA-AD가 가장 높았고, Moru wine 에서 가장 낮았다. 본 연구의 결과는 $M o r u$ wine의 총 플라보 노이드 함량을 567-1,092 $\mu \mathrm{g} / \mathrm{mL}$ 로 보고한 Kang 등(17)의 연구결과와 비교 시 Moru wine과 NA-VD 시료에서는 유사 하였으나 NA-AD는 높게 나타났다. 총 페놀화합물 함량은 Moru wine, NA-AD 및 NA-VD에서 각각 $1,955.00 \pm 75.35$, $3,345.14 \pm 65.72$ 및 $2,194.44 \pm 96.21 \mu \mathrm{g} / \mathrm{mL}$ 로 측정되었다. Moru wine의 총 페놀화합물 함량을 분석한 연구에서 $\mathrm{Kim}$ 등(18)은 2,669.37-2,765.67 $\mu \mathrm{g} / \mathrm{mL}$ 로, Kang 등(17)은 2,100$4,817 \mu \mathrm{g} / \mathrm{mL}$ 로 보고하여 본 연구에서 측정된 $M o r u$ wine의 총 페놀화합물 함량 결과와 큰 차이가 없었다. 하지만, $\mathrm{NA}-\mathrm{AD}$ 군 시료에서 다른 2종 시료들보다 총 페놀화합물 함량이 유의적으로 높았다 $(\mathrm{p}<0.05)$. ABTS 라디칼 제거능 은 Moru wine이 $92.61 \pm 0.1 \%$ 로 가장 낮았고 $(\mathrm{p}<0.05)$, $\mathrm{NA}-\mathrm{AD}$ 와 NA-VD는 각각 $98.11 \pm 0.16$ 와 $98.16 \pm 0.24 \%$ 로 나 타나서 두 시료들 사이에는 유의적인 차이가 없었다. $\mathrm{Kim}$ 등(19)은 적포도주는 가열처리 후에도 포도주의 주요성분 인 유기산과 페놀화합물은 소실되지 않았다고 보고하였다. 따라서 본 연구에서 측정된 시료들 간 총 플라보노이
드, 총 페놀화합물 함량 및 $\mathrm{ABTS}$ 라디칼 소거능의 차이는 무알코올 Moru wine을 제조하기 위한 증류 과정에서 알코 올과 일부 수분의 증발로 인한 농축효과로 예상할 수 있다. 이를 확인하기 위하여 온라인 HPLC로 $M o r u$ wine, NA-AD 및 NA-VD의 페놀화합물의 조성을 분석하였다.

\section{온라인 HPLC 항산화 분석(on-line HPLC-ABTS assay)}

3 종 시료들의 항산화 활성과 활성화 성분을 온라인 HPLC-ABTS법으로 분석하였다. 폴리페놀 표준물질들에 대해 정량 분석한 결과는 Fig. 1과 Table 3 에 나타내었다. 표준물질들과 시료에서 측정된 페놀성 물질들에 대한 크로 마토그램은 Fig. 1와 같다. Moru wine에서 검출된 주요 페놀 성 물질들은 gallic acid가 $10.35 \pm 0.01 \mu \mathrm{g} / \mathrm{mL}$ 로 가장 높게 나타났고, syringic acid $9.29 \pm 0.02 \mu \mathrm{g} / \mathrm{mL}$, vanillic acid $3.38 \pm 0.03 \mu \mathrm{g} / \mathrm{mL}$, caffeic acid $2.42 \pm 0.00 \mu \mathrm{g} / \mathrm{mL}$, rutin $2.32 \pm 0.20 \mu \mathrm{g} / \mathrm{mL}$, protocatechuic acid $2.02 \pm 0.00 \mu \mathrm{g} / \mathrm{mL}$ 순으 로 나타났다. 이외에도 미확인된 물질들(RT값 10 분대와 39 분대)이 함께 검출되었다. Kwon(20)은 본 연구에서 검출 된 물질 이외에도 머루에 함유된 주요 항산화물질이

Table 3. Polyphenol compounds in Moru wine and non-alcoholic Moru wine

\begin{tabular}{|c|c|c|c|}
\hline \multirow{2}{*}{ Compounds } & \multicolumn{3}{|c|}{ Concentration $(\mu \mathrm{g} / \mathrm{mL})$} \\
\hline & Moru wine & $\mathrm{NA}-A D^{1)}$ & $\mathrm{NA}-\mathrm{VD}^{2)}$ \\
\hline Gallic acid & $10.35 \pm 0.01^{3(4)}$ & $24.69 \pm 0.04^{\mathrm{a}}$ & $23.49 \pm 0.06^{b}$ \\
\hline Protocatechuic acid & $2.02 \pm 0.00^{c}$ & $6.84 \pm 0.44^{\mathrm{a}}$ & $4.74 \pm 0.04^{b}$ \\
\hline $\begin{array}{c}\text { Unknown } 1 \\
\text { (RT=10.2 min) }\end{array}$ & Not quantifiable & Not quantifiable & Not quantifiable \\
\hline Chlorogenic acid & $0.88 \pm 0.00^{\mathrm{c}}$ & $3.20 \pm 0.40^{b}$ & $4.12 \pm 0.14^{\mathrm{a}}$ \\
\hline Vanillic acid & $3.38 \pm 0.03^{\mathrm{c}}$ & $12.91 \pm 0.42^{\mathrm{a}}$ & $12.15 \pm 0.08^{\mathrm{b}}$ \\
\hline Caffeic acid & $2.42 \pm 0.00^{c}$ & $3.82 \pm 0.06^{\mathrm{b}}$ & $9.26 \pm 0.05^{\mathrm{a}}$ \\
\hline Syringic acid & $9.29 \pm 0.02^{\mathrm{c}}$ & $43.98 \pm 0.05^{\mathrm{a}}$ & $38.48 \pm 0.12^{\mathrm{b}}$ \\
\hline Epicatechin & $\mathrm{ND}^{5)}$ & $\mathrm{ND}$ & $\mathrm{ND}$ \\
\hline $\begin{array}{c}\text { Unknown } 2 \\
\text { (RT=26.6 min) }\end{array}$ & Not quantifiable & Not quantifiable & Not quantifiable \\
\hline $\mathrm{t}$-Ferulic acid & $0.54 \pm 0.02^{\mathrm{b}}$ & $1.25 \pm 0.04^{\mathrm{a}}$ & $1.38 \pm 0.25^{\mathrm{a}}$ \\
\hline Rutin & $2.32 \pm 0.20^{\mathrm{a}}$ & $2.30 \pm 0.02^{\mathrm{a}}$ & $2.04 \pm 0.05^{\mathrm{b}}$ \\
\hline Naringin & $0.36 \pm 0.02$ & $0.84 \pm 0.5^{6}$ & $0.55 \pm 0.02$ \\
\hline $\mathrm{t}$-Cinnamic acid & $0.32 \pm 0.04^{c}$ & $0.46 \pm 0.05^{\mathrm{b}}$ & $0.59 \pm 0.00^{\mathrm{a}}$ \\
\hline Naringenin & $\mathrm{ND}$ & $\mathrm{ND}$ & ND \\
\hline Kaempferol & $\mathrm{ND}$ & $\mathrm{ND}$ & $\mathrm{ND}$ \\
\hline Total & $31.88 \pm 0.18^{c}$ & $100.28 \pm 0.79^{\mathrm{a}}$ & $96.80 \pm 0.13^{b}$ \\
\hline
\end{tabular}

\footnotetext{
${ }^{11}$ Non-alcoholic Moru wine produced by atmospheric pressure method.

${ }^{2)}$ Non-alcoholic Moru wine produced by reduced pressure method.

${ }^{3)}$ All values are mean $\pm \mathrm{SD}(\mathrm{n}=3)$.

${ }^{4) a-c}$ Means with different superscripts in the same row are significantly different at $p<0.05$ by Duncan's multiple range test.

${ }^{5} \mathrm{ND}$, not detected.
} 
malvidin, petunidin, delphinidin, peonidin, cyanidin 및 resveratrol 등이 포함되어 있다고 보고하고 있다. 따라서 본 연구에서 나타난 미확인 물질들은 이들 물질을 비롯한 다양한 종류의 생리활성물질일 것으로 생각되며 이들 물질 들에 대한 추가적인 분석이 필요할 것으로 생각된다. $\mathrm{NA}-\mathrm{AD}$ 에서는 syringic acid가 $43.98 \pm 0.05 \mu \mathrm{g} / \mathrm{mL}$ 로 가장 높게 나타났으며, gallic acid 및 vanillic acid 등의 순으로 나타났고, NA-VD에서는 syringic acid, gallic acid 및 vanillic acid 순으로 나타났다. Koh(21)의 연구에 따르면 HPLC로 페놀성 물질을 분석한 결과 Moru wine에는 gallic acid가 8.8-53 $\mu \mathrm{g} / \mathrm{mL}$ 로 가장 높았고, chlorogenic acid, caffeic acid, protocatechuic acid, p-coumaric acid 및 syringic acid 순으로 나타났다. 본 연구와 타 연구에서 확인된 함량차이는 머루 의 재배지역, 숙성기간 및 양조기술 등에 의한 차이로 사료 된다. 3 종 시료들에서 각각 합산된 페놀성 물질들의 총 함량 은 Moru wine은 $31.88 \mu \mathrm{g} / \mathrm{mL}, \mathrm{NA}-\mathrm{AD}$ 는 $100.29 \mu \mathrm{g} / \mathrm{mL}$, NA-VD는 $96.80 \mathrm{\mu g} / \mathrm{mL}$ 로 나타나서 NA-AD, NA-VD, Moru wine 순으로 높았다 $(\mathrm{p}<0.05)$. 시료 간 총 페놀성물질 함량 차이는 증류과정중의 열처리에 의하여 농축효과 이외에도 증류과정에서 적용된 시료 전처리 조건이 영향을 주었을것 으로 추측할 수 있다. 본 연구에서는 무알코올 $M o r u$ wine 시료들인 NA-AD와 NA-VD 시료 $350 \mathrm{~mL}$ 제조를 위하 여 Moru wine 시료 $500 \mathrm{~mL}$ 를 사용하였다. 따라서, Moru wine 시료 $(500 \mathrm{~mL})$ 대비 무알코올 $M o r u$ wine 시료들의 $(350$ $\mathrm{mL}$ ) 시료 농축효과를 감안하더라도 Table 3에서 정량된 총 페놀성 화합물 함량 차이는 증류에 따른 Moru wine 화합 물들의 구조적 변화 가능성을 의미한다. 과일의 폴리페놀 화합물들은 배당체 형태로 다량 존재하며 산처리나 효소반 응에 의하여 가수분해되어 구조적으로 변화된 비배당체 형태로 변환된다(22). NA-AD와 NA-VD시료들에 측정된 상대적으로 높은 총 페놀성 화합물 함량은 증류조건에서 적용된 조건들이 비배당체 형태의 폴리페놀성 화합물 생성 을 촉진한 것으로 예상된다. 본 연구에서는 총 페놀성 화합 물 함량 측정에 적용한 분광광도계 측정값과 $\mathrm{HPLC}$ 측정값 간에 차이가 나타났다. 이러한 차이는, Folin-Ciocalteu's reaction법은 페놀성 물질들의 중합도에 관계없이 정량성을 나타내므로 Folin-Ciocalteu's 시약과 반응할 수 있는 다양한 종류의 물질들로 인하여 간섭요인들이 발생된 반면(13), 온라인 HPLC 항산화 분석법은 특정물질에 국한되어 결과 로 반영되므로 총 함량에서 차이가 나는 것으로 사료된다. $734 \mathrm{~nm}$ 파장에서 측정된 3종류 와인 시료들에 존재하는 물질 각각의 $\mathrm{ABTS}$ 라디칼 제거 정도를 negative peak

Table 4. Antioxidant activity of each polyphenol compounds in Moru wine and non-alcoholic Moru wine

\begin{tabular}{|c|c|c|c|}
\hline \multirow{2}{*}{ Compounds } & \multicolumn{3}{|c|}{ Negative peak area, $(\mathrm{mAU})$} \\
\hline & Moru wine & $\mathrm{NA}-\mathrm{AD}^{1)}$ & $\mathrm{NA}-\mathrm{VD}^{2)}$ \\
\hline Gallic acid & $819.57 \pm 0.40^{3 / 64)}$ & $1,612.76 \pm 24.53^{\mathrm{a}}$ & $1,584.03 \pm 9.44^{\mathrm{a}}$ \\
\hline Protocatechuic acid & $98.74 \pm 0.31^{\mathrm{b}}$ & $251.05 \pm 9.39^{\mathrm{a}}$ & $259.34 \pm 7.83^{\mathrm{a}}$ \\
\hline $\begin{array}{c}\text { Unknown } 1 \\
\text { (RT=10.2 min) }\end{array}$ & $274.06 \pm 0.21^{\mathrm{c}}$ & $1,049.07 \pm 0.82^{\mathrm{a}}$ & $1,013.98 \pm 1.63^{\mathrm{b}}$ \\
\hline Chlorogenic acid & $\mathrm{ND}^{5)}$ & $47.96 \pm 0.63^{\mathrm{a}}$ & $42.37 \pm 5.42^{b}$ \\
\hline Vanillic acid & $9.88 \pm 0.11^{\mathrm{b}}$ & $39.01 \pm 1.76^{\mathrm{a}}$ & $39.41 \pm 1.30^{\mathrm{a}}$ \\
\hline Caffeic acid & $69.22 \pm 0.46^{\mathrm{c}}$ & $194.92 \pm 2.19^{\mathrm{b}}$ & $233.72 \pm 2.75^{\mathrm{a}}$ \\
\hline Syringic acid & $40.85 \pm 0.69^{c}$ & $118.51 \pm 0.41^{\mathrm{a}}$ & $118.39 \pm 4.07^{\mathrm{a}}$ \\
\hline Epicatechin & ND & ND & $\mathrm{ND}$ \\
\hline $\begin{array}{c}\text { Unknown } 2 \\
\text { (RT=26.6 min) }\end{array}$ & $604.16 \pm 3.58^{\mathrm{c}}$ & $1,689.30 \pm 2.06^{\mathrm{a}}$ & $1,628.69 \pm 5.49^{b}$ \\
\hline $\mathrm{t}$-Ferulic acid & $27.76 \pm 6.26^{b}$ & $92.03 \pm 3.21^{\mathrm{a}}$ & $65.89 \pm 2.27^{b}$ \\
\hline Rutin & $97.07 \pm 12.89$ & $90.93 \pm 0.39$ & $99.33 \pm 2.39$ \\
\hline Naringin & $34.05 \pm 1.74^{\mathrm{a}}$ & $33.30 \pm 2.12^{\mathrm{a}}$ & $23.33 \pm 0.68^{\mathrm{b}}$ \\
\hline $\mathrm{t}$-Cinnamic acid & $76.11 \pm 0.91^{\mathrm{c}}$ & $134.93 \pm 1.82^{\mathrm{a}}$ & $115.85 \pm 5.21^{\mathrm{b}}$ \\
\hline Naringenin & ND & ND & ND \\
\hline Kaempferol & ND & ND & ND \\
\hline Total & $2,151.47 \pm 282.39^{c}$ & $5,353.76 \pm 626.80^{\mathrm{a}}$ & $5,224.33 \pm 609.24^{b}$ \\
\hline
\end{tabular}

\footnotetext{
${ }^{1)}$ Non-alcoholic Moru wine produced by atmospheric pressure method.

${ }^{2)}$ Non-alcoholic Moru wine produced by reduced pressure method.

${ }^{3)}$ All values are mean $\pm \mathrm{SD} \quad(\mathrm{n}=3)$.

${ }^{4) a-c}$ Means with different superscripts in the same row are significantly different at $\mathrm{p}<0.05$ by Duncan's multiple range test.

${ }^{5} \mathrm{ND}$, not detected.
} 
$\operatorname{area(mAU)}$ 의 면적으로 비교하였다(Fig. 1, Table 4). Moru wine군 시료에서는 ABTS 라디칼 제거능을 보이는 물질은 gallic acid, protocatechuic acid 및 rutin 순으로 나타났으며, $\mathrm{NA}-\mathrm{AD}$ 군 및 NA-VD군에서는 gallic acid, protocatechuic acid 및 caffeic acid 순으로 나타났다. 또한, Moru wine보다 무알코올 Moru wine인 NA-AD와 NA-VD 시료들에서 $\mathrm{ABTS}$ 라디칼 소거능이 더 뛰어난 것을 확인할 수 있었다. 이러한 결과는 분광광도계로 측정한 $\mathrm{ABTS}$ 라디칼 소거능 결과(Table 3)와 유사한 경향을 보였다. Choi 등(23)은 포도 주의 항산화력과 항산화성분 간의 상관분석 결과 총 안토시 아닌 함량과 항산화력 간에는 어떠한 상관성도 존재하지 않은 반면, 총 폴리페놀 성분과 ABTS 라디칼 제거능, 2,2-diphenyl-1-picrylhydrazyl(DPPH) 라디칼 제거능 및 환 원력에는 상당한 상관성이 존재한다고 보고하여 $\mathrm{Moru}$ wine의 항산화력 또한 포도주와 유사하게 폴리페놀 물질과 의 연관성이 높다고 생각된다. 포도주의 항산화활성 측정 을 위하여 인위적으로 만들어낸 라디칼을 제거하는 능력을 소거시키는 능력을 분광광도계를 사용하여 측정하는 방법 이 이용되고 있으며 여기에는 $\mathrm{ABTS}$ 라디칼 제거능 측정법 과 $\mathrm{DPPH}$ 라디칼 제거능 측정법이 포함된다(24). 하지만 이러한 방법들은 시료에 들어있는 항산화 물질들을 여러 방법으로 분리한 후 각 물질들의 항산화도를 개별적으로 측정하기 때문에 번거롭고, 많은 시간이 소요된다(25). 이 러한 불편한 점들을 해결하기 위하여 측정하고자 하는 물질 들의 분리와 동시에 각 물질들의 라디칼 제거능을 측정할 수 있는 온라인 HPLC 항산화 분석법(14)을 본 연구에 적용 하였다. 본 연구의 결과로는 그 중 gallic acid와 syringic acid가 Moru wine 및 무알코올 Moru wine의 항산화능에 큰 기여를 하는 물질들로 나타났다.

결론적으로, Moru wine을 증류시켜 무알코올 Moru wine 제조 시, 산도와 가용성 고형분 함량에서는 차이가 있었으 며, 특히 페놀성물질의 함량이 증류과정에서 증가하는 것 으로 나타났다. 무알코올 Moru wine은 Moru wine에 비교하 여 높은 함량의 폴리페놀 화합물에 의한 강력한 항산화활성 을 지닌다는 장점이 있음을 확인하였음으로 무알코올 Moru wine의 관능적인 개선이 담보된다면 건강지향적 소 비자들의 요구에 부합되는 식품으로 개발가능성이 높을 것으로 생각된다.

\section{요 약}

본 연구에서는 Moru wine, 상압증류법 및 감압증류법으 로 제조한 무알코올 Moru wine의 이화학적 특성 및 항산화 활성을 비교하였다. 무알코올 Moru wine 제조를 위하여 Moru wine을 상압증류(NA-AD) 또는 감압증류 $80 \mathrm{mbar}$, $55^{\circ} \mathrm{C}, \mathrm{NA}-\mathrm{VD}$ )하였다. 3 종 시료들 중에서 산도는 $\mathrm{NA}-\mathrm{VD}$ 에
서 가장 높았고, 가용성 고형분값은 Moru wine 시료에서 유의적으로 높았다(p<0.05). 무알코올 Moru wine 시료인 $\mathrm{NA}-\mathrm{AD}$ 의 총 플라보노이드 함량, 총 페놀 함량 및 $\mathrm{ABTS}$ 라디칼 소거능이 가장 높았다 $(\mathrm{p}<0.05)$. 온라인 HPLC 항산 화 분석 시 Moru wine과 무알코올 Moru wine 시료들 간에 폴리페놀 물질 조성에서 뚜렷한 차이가 있었다. 최소 10 종 이상(gallic acid, protocatechuic acid, chlorogenic acid, vanillic acid, cafferic acid, syringic acid, t-ferulic acid, rutin, naringin 및 t-cinnamic acid)의 다른 폴리페놀 물질들이 Moru wine과 무알코올 Moru wine에서 확인되었다. Gallic $\operatorname{acid}(10.35-24.69 \mu \mathrm{g} / \mathrm{mL})$ 와 syringic $\operatorname{acid}(9.29-43.98 \mu \mathrm{g} / \mathrm{mL})$ 가 주요 폴리페놀 물질로 판명되었다.

\section{감사의 글}

본 논문은 2017년도 강원대학교 대학회계 학술연구조성 비(관리번호-620170124)에 의해 수행되었습니다.

\section{References}

1. Park HS (2010) Physicochemical property and antioxidant activity of wild grape (Vitis coignetiea) juice. Korean J Culinary Res, 16, 297-304

2. Oh HJ, Lim SB (2017) Quality changes in kiwifruit wines during fermentation and aging with different yeasts. J Korean Soc Food Sci Nutr, 46, 481-489

3. Lee JH, Kang TH, Um BH, Sohn EH, Han WC, Ji SH, Jang KH (2012) Evaluation of physicochemical and fermentation qualities of Moru wines supplemented with pine needles or medicinal herbs. J East Asian Soc Diet Life, 22, 886-894

4. Choi JY, Lee SJ, Lee SJ, Park SM, Lee JH, Shim JH, El-Aty AMA, Jin JS, Jeong ED, Lee WS, Shin SC (2010) Analysis and tentative structure elucidation of new anthocyanins in fruit peel of Vitis coignetiae pulliat (Meoru) using LC-MS/MS: Contribution to the overall antioxidant activity. J Sep Sci, 33, 1192-1197

5. Kim NY, Kim YK, Bae KJ, Choi JH, Moon JH, Park GH, Oh DH (2005) Free radical scavenging effect and extraction condition of ethanol extracts and fractions of wild grape seed (Vitis coignetiea). J Korean Soc Food Sci Nutr, 34, 755-758

6. Lee BY, Lee ME, O JH, Kim EC, Surh JH (2010) Preparation and characterization of physicochemical and sensory properties of bread enriched with two types of 
wild grape extract. Korean J Food Cook Sci, 26, 636-648

7. Min YK, Yun HS, Jeong HS, Jang YS (1992) Changes in compositions of liquor fractions distilled from Samil-ju with various distillation conditions. Korean J Food Sci Technol, 24, 440-446

8. In HY, Lee TS, Lee DS, Noh BS (1995) Volatile components and fusel oils of sojues and mashes brewed by Korean traditional method. Korean J Food Sci Technol, 27, 235-240

9. Cho HC, Kang SA, Choi SI, Cheong C (2013) Quality characteristics of fruit spirits from a copper distillation apparatus. J Korean Soc Food Sci Nutr, 42, 743-752

10. Zhishen J, Mengcheng T, Jianming W (1999) The determination of flavonoid contents in mulberry and their scavenging effects on superoxide radicals. Food Chem, 64, 555-559

11. Folin O, Ciocalteu V (1927) On tyrosine and tryptophane determinations in proteins. $\mathrm{J}$ Biol Chem, 73, 627-650

12. Nam DH, Jang EH, Jang KH, Lee JC (2018) Radical scavenging activity of domestic fruit wine. Korean J Food Preserv, 25, 351-358

13. Jeong IH, Oh MS, Jeon JS, Kim HT, Hong SR, Park $\mathrm{KH}$, Yoon $\mathrm{MH}$ (2017) A comparative study on anthocyanin and polyphenol contents in colored agricultural products. J Food Hyg Saf, 32, 371-380

14. Niederlander HAG, van Beek TA, Bartasiute A, Koleva II (2008) Antioxidant activity assays on-line with liquid chromatography. J Chromatogr A, 1210, 121-134

15. Ji SH, Han WC, Lee JC, Kim BW, Jang KH (2009) Fermentation characteristics of Moru wine fermented with Rose rugoga Thun. Korean J Food Sci Thechnol, 41, 186-190

16. Sung NH, Jo YJ, Park CW, Woo SM, Jang SY, Choi
IW, Jeong YJ (2012) Characteristics of alcohol fermentation in citrus hydrolysates through narirutin addition. Korean J Food Preserv, 19, 153-158

17. Kang BT, Yoon OH, Lee JW, Kim SH (2009) Qualitative properties of wild grape wine having different aging periods. Korean J Food Nutr, 22, 548-553

18. Kim CW, Jeon JA, Kang JE, Choi HS, Yeo SH, Jeong ST (2016) Characteristics of Gaeryangmerou wine deacidified by calcium carbonate. J East Asian Soc Diet Life, 26, 559-564

19. Kim HY, Ko SH, Lee KY (2010) Quality characteristics of sauteing chili sauce shrimp with red wine. Korean J Food Cook Sci, 26, 358-366

20. Kwon YH (2012) Growth characteristics and functional compounds in 'Gaeryangmeoru' grapes in Korea. $\mathrm{PhD}$ Thesis, Chungang University, Korea, p 65-76

21. Koh KH (2000) Study on the improvement of Moru-ju marking and healthy functional activity. Taesan Reports, 8, 193-205

22. Hertog MGL, Hollman PCH, Venema DP (1992) Optimization of a quantitative HPLC determination of potentially anticarcinogenic flavonoids in vegetables and fruits. J Agric Food Chem, 40, 1591-1598

23. Choi YM, Yu KW, Han NS, Koh JH, Lee JS (2006) Antioxidant activities and antioxidant compounds of commercial red wines. J Korean Soc Food Sci Nutr, 35, 1286-1290

24. Blois MS (1958) Antioxidant determinations by the use of a stable free radical. Nature, 181, 1199-1200

25. Kim SJ, Kim SM, Kang SW, Um BH (2010) The rapid detection of antioxidants from safflower seeds (Carthamus tinctorius L.) using hyphenated-HPLC techniques. Korean J Food Sci Technol, 42, 414-419 